Cochrane Database of Systematic Reviews

\title{
Gamma aminobutyric acid (GABA) modulators for amyotrophic lateral sclerosis/motor neuron disease (Review)
}

Diana A, Pillai R, Bongioanni P, O'Keeffe AG, Miller RG, Moore DH

Diana A, Pillai R, Bongioanni P, O'Keeffe AG, Miller RG, Moore DH.

Gamma aminobutyric acid (GABA) modulators for amyotrophic lateral sclerosis/motor neuron disease.

Cochrane Database of Systematic Reviews 2017, Issue 1. Art. No.: CD006049.

DOI: 10.1002/14651858.CD006049.pub2.

www.cochranelibrary.com 
TABLE OF CONTENTS

HEADER 1

ABSTRACT

PLAIN LANGUAGE SUMMARY

SUMMARY OF FINDINGS

BACKGROUND

OBJECTIVES

METHODS

Figure 1.

RESULTS

Figure 2.

DISCUSSION

AUTHORS' CONCLUSIONS

ACKNOWLEDGEMENTS

REFERENCES

CHARACTERISTICS OF STUDIES

DATA AND ANALYSES

Analysis 1.1. Comparison 1 Gabapentin versus placebo, Outcome 1 Adverse events. APPENDICES

HISTORY

CONTRIBUTIONS OF AUTHORS

DECLARATIONS OF INTEREST

SOURCES OF SUPPORT

DIFFERENCES BETWEEN PROTOCOL AND REVIEW

NOTES

INDEX TERMS

1

2

4

7

7

7

9

10

11

15

15

15

16

17

20

21

23

26

26

27

27

27

27 
[Intervention Review]

\title{
Gamma aminobutyric acid (GABA) modulators for amyotrophic lateral sclerosis/motor neuron disease
}

\author{
Andrea Dianaํㅡ, Rita Pillai ${ }^{1}$, Paolo Bongioanni², Aidan G O'Keeffe ${ }^{3}$, Robert G Miller4, Dan H Moore 5 \\ 1Department of Biomedical Sciences, University of Cagliari, Monserrato (Cagliari), Italy. ${ }^{2}$ Neurorehabilitation Unit, Department of \\ Neuroscience, University of Pisa, Pisa, Italy. ${ }^{3}$ Department of Statistical Science, University College London, London, UK. ${ }^{4}$ Forbes Norris \\ ALS Research Center, California Pacific Medical Center, San Francisco, USA. ${ }^{2}$ Research Institute, California Pacific Medical Center, San \\ Francisco, CA, USA
}

Contact address: Andrea Diana, Department of Biomedical Sciences, University of Cagliari, Citta Universitaria di Monserrato (Cagliari), Monserrato (Cagliari), 09042, Italy. diana@unica.it.

Editorial group: Cochrane Neuromuscular Group.

Publication status and date: New, published in Issue 1, 2017.

Citation: Diana A, Pillai R, Bongioanni P, O'Keeffe AG, Miller RG, Moore DH. Gamma aminobutyric acid (GABA) modulators for amyotrophic lateral sclerosis/motor neuron disease. Cochrane Database of Systematic Reviews 2017, Issue 1. Art. No.: CD006049. DOI: 10.1002/14651858.CD006049.pub2.

Copyright () 2017 The Cochrane Collaboration. Published by John Wiley \& Sons, Ltd.

\section{A B S T R A C T}

\section{Background}

Imbalance of gamma aminobutyric acid (GABA) and related modulators has been implicated as an important factor in the pathogenesis of amyotrophic lateral sclerosis (ALS), which is also known as motor neuron disease (MND). In this context, the role and mechanism of action of gabapentin and baclofen have been extensively investigated, although with conflicting results. This is the first systematic review to assess clinical trials of GABA modulators for the treatment of ALS.

\section{Objectives}

To examine the efficacy of gabapentin, baclofen, or other GABA modulators in delaying the progression of ALS, and to evaluate adverse effects of these interventions.

\section{Search methods}

On 16 August 2016, we searched the Cochrane Neuromuscular Specialised Register, Cochrane Central Register of Controlled Trials (CENTRAL), MEDLINE, Embase, CINAHL Plus, AMED, and LILACS. In addition, we checked the bibliographies of the trials found in order to identify any other trials, and contacted trial authors to identify relevant unpublished results or additional clinical trials. On 30 August 2016 , we searched two clinical trials registries.

\section{Selection criteria}

Types of studies: double-blind randomized controlled trials (RCTs) or quasi-RCTs

Types of participants: adults with a diagnosis of probable or definite ALS

Types of interventions: gabapentin, baclofen, or other GABA modulators compared with placebo, no treatment, or each other Primary outcome: survival at one year from study enrollment

Secondary outcomes: individual rate of decline of maximum voluntary isometric contraction (MVIC), expressed as arm megascore; rate of decline of per cent predicted forced vital capacity (FVC); rate of decline of ALS Functional Rating Scale (ALSFRS); health-related quality of life; survival evaluated by pooling hazards; and adverse events 


\section{Data collection and analysis}

At least two review authors independently checked titles and abstracts identified by the searches. The review authors obtained and independently analyzed original individual participant data from each included study; additional review authors and the Cochrane Neuromuscular Managing Editor checked the outcome data. Two authors independently assessed the risk of bias in included studies.

\section{Main results}

We identified two double-blind RCTs of gabapentin treatment in ALS for inclusion in this review. We found no eligible RCTs of baclofen or other GABA modulators. The selected studies were phase II and phase III trials, which lasted six and nine months, respectively. They were highly comparable because both were comparisons of oral gabapentin and placebo, performed by the same investigators. The trials enrolled 355 participants with ALS: 80 in the gabapentin group and 72 in the placebo group in the first (phase II) trial and 101 in the gabapentin group and 102 in the placebo group in the second (phase III) trial. Neither trial was long enough to report survival at one year, which was our primary outcome. We found little or no difference in estimated one-year survival between the treated group and the placebo group (78\% versus $77 \%, P=0.63$ by log-rank test; high-quality evidence). We also found little or no difference in the rate of decline of MVIC expressed as arm megascore, or rate of FVC decline (high-quality evidence). One trial investigated monthly decline in the ALSFRS and quality of life measured using the 12-Item Short Form Survey (SF-12) and found little or no difference between groups (moderatequality evidence). The trials reported similar adverse events. Complaints that were clearly elevated in those taking gabapentin, based on analyses of the combined data, were light-headedness, drowsiness, and limb swelling (high-quality evidence). Fatigue and falls occurred more frequently with gabapentin than with placebo in one trial, but when we combined the data for fatigue from both trials, there was no clear difference between the groups. We assessed the overall risk of bias in the included trials as low.

\section{Authors' conclusions}

According to high-quality evidence, gabapentin is not effective in treating ALS. It does not extend survival, slow the rate of decline of muscle strength, respiratory function and, based on moderate-quality evidence, probably does not improve quality of life or slow monthly decline in the ALSFRS. Other GABA modulators have not been studied in randomized trials.

\section{PLAIN LANGUAGE SUMMARY}

\section{Gamma aminobutyric acid modulators for amyotrophic lateral sclerosis/motor neuron disease}

\section{Review question}

Do medicines that promote the effects of the brain chemical gamma aminobutyric acid (GABA) delay the progression of amyotrophic lateral sclerosis (ALS)?

\section{Background}

ALS, which is also known as motor neuron disease (MND), is a condition that affects motor neurons in the brain and spinal cord. A person with ALS gradually loses the ability to control movement. In about two-thirds of people with ALS, the condition affects the arms first, and difficulty walking will follow. The muscles of the throat can also become weak, which affects swallowing and speaking. As the disease progresses, muscle wasting worsens, with stiffness, cramping and loss of the ability to move. Death generally occurs within two to five years.

Glutamate is a chemical mediator in the brain that stimulates motor neurons. Glutamate overproduction is probably responsible for motor neuron damage in ALS. The molecule GABA acts to lessen the effects of glutamate. Medicines that increase GABA activity (GABA modulators), such as gabapentin and baclofen, are possible treatments for ALS. This is the first systematic review of the evidence from clinical trials of GABA modulators for ALS.

\section{Study characteristics}

A systematic search of the medical literature found two randomized trials of gabapentin compared with placebo (inactive treatment). The same team of scientists performed both trials, which were sponsored by the manufacturer. The trials involved a total of 355 people with ALS. Treatment with gabapentin lasted six and nine months. We found no trials of baclofen or other GABA modulators in ALS that met our selection criteria. We assessed the gabapentin trials as well run and well conducted.

\section{Key results and quality of the evidence}

Neither of the trials were long enough to for us to report survival at one year. Combined results from the two studies (based on 274 participants) provided high-quality evidence of little or no difference in estimated one-year survival, the rate of decline in respiratory function, or rate of decline in arm strength in people treated with gabapentin compared to those treated with placebo. One trial (128 participants) measured quality of life and monthly decline in function (measured by the ALS Functional Rating Scale). There was little or no difference in the ALS Functional Rating Scale (ALSFRS) or quality of life between the gabapentin group and the placebo group. 
People who received gabapentin had more light-headedness, drowsiness, and limb swelling than those taking placebo when we combined data from both trials (353 participants). Fatigue and falls occurred more frequently with gabapentin than with placebo in one trial, but when we combined the data for fatigue from both trials, there was no clear difference between the groups.

In conclusion, high-quality evidence indicates that gabapentin does not extend survival or slow the rate of decline of muscle strength or respiratory function. Moderate-quality evidence shows no effect on quality of life or decline in ALSFRS. Other GABA modulators have not been studied in randomized trials.

The evidence is current to August 2016. 


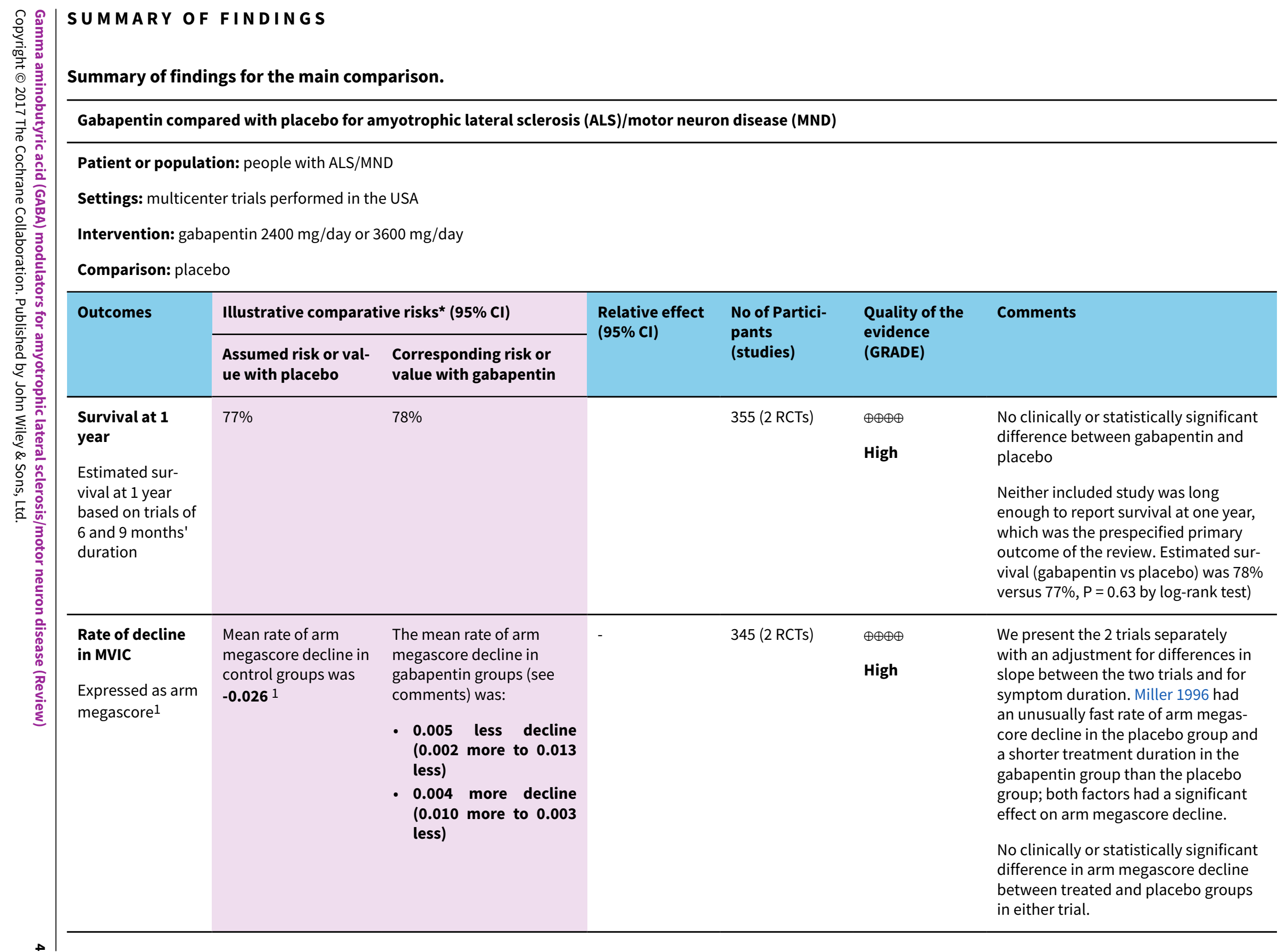




\begin{tabular}{|c|c|c|c|c|c|}
\hline $\begin{array}{l}\text { Rate of decline } \\
\text { of } \% \text { predicted }\end{array}$ & $\begin{array}{l}\text { The rate of FCV de- } \\
\text { cline in control } \\
\text { groups was } 0.593 \text { to } \\
\mathbf{0 . 6 5} 3\end{array}$ & $\begin{array}{l}\text { The mean rate of FVC de- } \\
\text { cline in the gabapentin } \\
\text { group was } 0.057 \text { more de- } \\
\text { cline ( } 0.21 \text { more to } 0.09 \\
\text { less) }\end{array}$ & 274 (2 RCTs) & $\begin{array}{l}\oplus \oplus \oplus \oplus \\
\text { High }\end{array}$ & $\begin{array}{l}\text { No clinically or statistically significant } \\
\text { difference between gabapentin and } \\
\text { placebo }\end{array}$ \\
\hline $\begin{array}{l}\text { Rate of decline } \\
\text { (per month) of } \\
\text { functional rating } \\
\text { scale (over a peri- } \\
\text { od of } 9 \text { months) } \\
\text { Measured by } \\
\text { ALSFRS-R }\end{array}$ & $\begin{array}{l}\text { The control rate of } \\
\text { decline of ALSFRS-R } \\
\text { was } \mathbf{0 . 0 7 6} 4\end{array}$ & $\begin{array}{l}\text { The rate of ALSFRS-R de- } \\
\text { cline was } 0.015 \text { less de- } \\
\text { cline }(0.34 \text { more to } 0.05 \\
\text { less) }\end{array}$ & $\begin{array}{l}128 \\
(1 \mathrm{RCT})\end{array}$ & $\begin{array}{l}\oplus \oplus \oplus \ominus \\
\text { Moderate } 5\end{array}$ & $\begin{array}{l}\text { No clinically or statistically significant } \\
\text { difference between gabapentin and } \\
\text { placebo }\end{array}$ \\
\hline $\begin{array}{l}\text { Health-related } \\
\text { quality of life } \\
\text { Short Form } 12 \\
\text { Health Survey } \\
\text { (SF-12) }\end{array}$ & \multicolumn{2}{|c|}{$\begin{array}{l}\text { Miller } 2001 \text { reported little or no difference between } \\
\text { treatment and placebo groups in the SF- } 12 \text { (Phys- } \\
\text { ical), with a mean change }( \pm S D) \text { of }-0.03( \pm 0.7) \text { on } \\
\text { gabapentin and }-0.2( \pm 0.5) \text { on placebo }(P=0.19)\end{array}$} & 128 (1 RCT) & $\begin{array}{l}\oplus \oplus \oplus \ominus \\
\text { Moderate } 5\end{array}$ & - \\
\hline Adverse events & \multicolumn{2}{|c|}{$\begin{array}{l}\text { The trials did not report an overall adverse event } \\
\text { rate. Light-headedness, drowsiness, falls and } \\
\text { swelling were reported in both trials and were sig- } \\
\text { nificantly more common with gabapentin than } \\
\text { with placebo. Adverse event reporting was incom- } \\
\text { plete in one of the trial reports }\end{array}$} & 353 (2 RCTs) & $\begin{array}{l}\oplus \oplus \oplus \oplus \\
\text { High }\end{array}$ & - \\
\hline \multicolumn{6}{|c|}{$\begin{array}{l}\text { *The basis for the assumed risk (e.g. the median control group risk across studies) is provided in footnotes. The corresponding risk (and its } 95 \% \text { confidence interval) is } \\
\text { based on the assumed risk in the comparison group and the relative effect of the intervention (and its 95\% CI). } \\
\text { ALS: amyotrophic lateral sclerosis; ALSFRS-R: Amyotrophic Lateral Sclerosis Functional Rating Score-Revised; Cl: confidence interval; FVC: forced vital capacity; MND: mo- } \\
\text { tor neuron disease; MVIC: maximum voluntary isometric contraction; RCT: randomized controlled trial; RR: risk ratio; SD: standard deviation; vs: versus }\end{array}$} \\
\hline \multicolumn{6}{|c|}{$\begin{array}{l}\text { GRADE Working Group grades of evidence } \\
\text { High quality: Further research is very unlikely to change our confidence in the estimate of effect. } \\
\text { Moderate quality: Further research is likely to have an important impact on our confidence in the estimate of effect and may change the estimate. } \\
\text { Low quality: Further research is very likely to have an important impact on our confidence in the estimate of effect and is likely to change the estimate. } \\
\text { Very low quality: We are very uncertain about the estimate. }\end{array}$} \\
\hline
\end{tabular}

1. This is the pooled mean rate of decline from the two studies, as reported in Miller 2001.

2. We used a linear mixed effect model to account for differences in slopes between the two trials and for symptom duration. One of the trials (the phase II, Miller 1996) had an unusually rapid placebo group decline.

3. The basis for the assumed risk is the combined fit of FVC slopes from the 2 included studies.

4. The basis for the assumed risk is the placebo group ALSFRS-R slope. 


\section{B A C K G R O U N D}

\section{Description of the condition}

Amyotrophic lateral sclerosis (ALS), which is also known as motor neuron disease (MND), Lou Gehrig's or Charcot's disease, is a neurodegenerative disorder characterized by loss of motor neurons of the cerebral cortex, brain stem, and spinal cord. The condition results in progressive weakness and paralysis of voluntary muscles, which ultimately leads to death. Median prevalence (per 100,000 population) has been estimated as 5.4 (interquartile range (IQR) 4.06 to 7.89 ) in Europe and 3.4 (IQR 3.15 to 3.65 ) in the USA (Chio 2013). Although the cause of ALS remains unknown, so-called excitotoxicity induced by an imbalance of the excitatory neurotransmitter glutamate and inhibitory neurotransmitter gamma aminobutyric acid (GABA) appears to be important in pathogenesis, because excitotoxicity is thought to trigger irreversible cell damage (for a review, see Rao 2004). Glutamate has been suggested as a possible chemical insult for triggering the slow neuronal demise and related abnormalities in glutamate metabolism seen in ALS, which include elevated glutamate levels in cerebrospinal fluid (CSF) (Plaitakis 1987; Rothstein 1991; Shaw 1995; Spreux-Varoquaux 2002). The discovery that GABA content is increased in the serum and CSF of people with ALS led investigators to consider its possible contribution to ALS pathogenesis (Niebroj-Dobosz 1999). In addition, anatomical analysis of human postmortem brains revealed a significantly reduced expression of messenger ribonucleic acid (mRNA) for the GABA receptor subunit (alpha1subunit) (Petri 2003). These findings correspond with those of a positron emission tomography study using the ligand flumazenil that showed downregulation of GABA receptors, which is likely to reflect a loss of interneuronal function (Lloyd 2000). However, electrophysiological measurements revealed no correlation between the ALS hyperexcitability index in different motor units and changes in serum and CSF levels of GABA (Kostera 2002).

\section{Description of the intervention}

Pharmacological reversal of cortical hyperexcitability in people with ALS has been observed after sustained treatment with GABA modulators such as gabapentin (Caramia 2000), even though experiments with rat neocortical slices found no effect of gabapentin on GABA release because of the selective activation of presynaptic GABA-B heteroreceptors (Parker 2004).

Baclofen is a GABA agonist with some efficacy in reducing spasticity of cerebral or spinal origin in people with ALS (Norris 1979).

\section{How the intervention might work}

The above studies indicate that the mechanism of action of gabapentin is still controversial (Taylor 1994; Taylor 1998). They provided a rationale for undertaking clinical trials of gabapentin in ALS, despite the fact that gabapentin is not a structural analog of GABA (Satzinger 1994), but simply a compound with conformational properties that mimic its amino acid structure (Bryans 1999). Although the evidence supporting a role for GABA is under debate, sufficient data exist to justify trials of the GABA agonist baclofen or the GABA modulator gabapentin in ALS.

\section{Why it is important to do this review}

While treatment for spasticity and cramps in ALS have been the subjects of other reviews (Ashworth 2012; Baldinger 2012), no systematic review has addressed the benefit of GABA modulators such as gabapentin or baclofen in slowing the clinical progression of ALS. Thus, the specific aim of this review is to assess the clinical impact of GABA modulators as disease-modifying agents.

\section{O B JECTIVES}

To examine the efficacy of gabapentin, baclofen, or other GABA modulators in delaying the progression of ALS, and to evaluate adverse effects of these interventions.

\section{METHO D S}

\section{Criteria for considering studies for this review}

\section{Types of studies}

We considered for inclusion double-blind, randomized controlled trials (RCTs) and quasi-RCTs of gabapentin, baclofen, or other GABA modulators in the treatment of ALS. Quasi-RCTs use methods of allocation that are partly systematic, such as allocation by alternate days, date of birth, or hospital number.

\section{Types of participants}

We considered for inclusion adults with a clinical and laboratorysupported diagnosis of probable or definite ALS that conformed to the criteria of the World Federation of Neurology (WFN) Research Group (Brooks 2000).

\section{Types of interventions}

We considered for inclusion gabapentin, baclofen, or other GABA modulators compared with placebo, no treatment, or each other.

\section{Types of outcome measures}

\section{Primary outcomes}

Survival at one year from study enrollment.

\section{Secondary outcomes}

1. Individual rate of decline of maximum voluntary isometric contraction (MVIC), expressed as arm megascore.

2. Rate of decline of percent predicted forced vital capacity (FVC).

3. Rate of decline of ALS Functional Rating Scale (ALSFRS) (Cedarbaum 1999).

4. Health-related quality of life assessed by means of a validated multipurpose scale, such as the 36-Item Short Form Health Survey (Rand 2016).

5. Survival evaluated by pooling hazards using methods described by Parmar 1998 when study data are sufficiently detailed (i.e. when survival in each group is reported as numbers at risk and numbers dying at follow-up intervals, e.g. quarterly or semiannually). If such data are not available for all studies, we will use other approaches, such as generalized inverse variance on reported hazard ratios and their standard errors.

6. Adverse events, namely side effects such as light-headedness, drowsiness, weakness, daytime fatigue, nausea, anorexia, or weight loss. We based comparisons on analyses of $2 \times 2$ tables 
summarizing numbers of events in each group, regardless of time of occurrence.

We planned to base measurement of rates on the length of followup for the trial. If the lengths of follow-up differed, we planned to conduct a subgroup analysis to determine whether length of followup influenced the rate of decline in different trials.

\section{Search methods for identification of studies}

\section{Electronic searches}

On 16 August 2016, we searched the Cochrane Neuromuscular Specialised Register, Cochrane Central Register of Controlled Trials (CENTRAL) in the in the Cochrane Register of Studies (CRS) online, MEDLINE (January 1966 to August 2016), Embase (January 1980 to August 2016), CINAHL Plus (Cumulative Index to Nursing and Allied Health Literature; January 1982 to August 2016), AMED (Allied and Complementary Medicine; January 1985 to August 2016), and LILACS (Latin American and Caribbean Health Science Information database; January 1982 to August 2016). On 30 August 2016, we also searched US National Institutes of Health Ongoing Trials Register ClinicalTrials.gov and the World Health Organization International Clinical Trials Registry Platform (ICTRP; www.who.int/ictrp/en/).

The detailed search strategies are in the appendices: Cochrane Neuromuscular Specialised Register (Appendix 1), MEDLINE (Appendix 2), Embase (Appendix 3), AMED (Appendix 4), CINAHL Plus (Appendix 5), LILACS (Appendix 6), CENTRAL (Appendix 7), ClinicalTrials.gov (Appendix 8), and ICTRP (Appendix 9).

\section{Searching other resources}

We checked the bibliographies of the trials found in order to identify references to other trials. In addition, we contacted authors of trials to identify relevant unpublished results or clinical trials.

\section{Data collection and analysis}

\section{Selection of studies}

Two or three review authors (from among AD, DHM and RP) independently checked all titles and abstracts identified by the searches. The same review authors independently examined the full-text reports of the collected papers in order to select trials that fit the inclusion criteria for the review. There was no disagreement on study selection.

We included a PRISMA flow chart to illustrate the study selection process and noted the reasons for study exclusion in sufficient detail for completion of a Characteristics of excluded studies table.

\section{Data extraction and management}

We were able to obtain the original data for each participant in all included trials from the trial authors, two of whom are authors of this review. For each study, we had original raw data for every participant for all outcome endpoints. We then combined all original data into one dataset, which facilitated statistical analyses. A statistician independent of the trials $\left(\mathrm{AO}^{\prime} \mathrm{K}\right)$ and the Managing Editor of Cochrane Neuromuscular double-checked the data in the review to ensure accuracy.

\section{Assessment of risk of bias in included studies}

Two review authors ( $A D$ and $R P$ ) independently assessed the risk of bias in each included study. We would have resolved disagreement by consensus, but none occurred. Each review author assessed the risk of bias of the studies, taking into account the following parameters: security of randomization, allocation concealment, blinding of participants and personnel, blinding of outcome assessors, completeness of outcome data, selective outcome reporting, and other sources of bias, according to the methods set out in the Cochrane Handbook for Systematic Reviews of Interventions (Higgins 2011). We made judgements for each domain of low, high, or unclear risk of bias. We included a 'Risk of bias' summary figure showing the assessments for the included studies (Figure 1). 
Figure 1. Risk of bias summary: review authors' judgements about each risk of bias item for each included study. Green $=$ low risk of bias, yellow $=$ unclear risk of bias, red (not shown) $=$ high risk of bias.

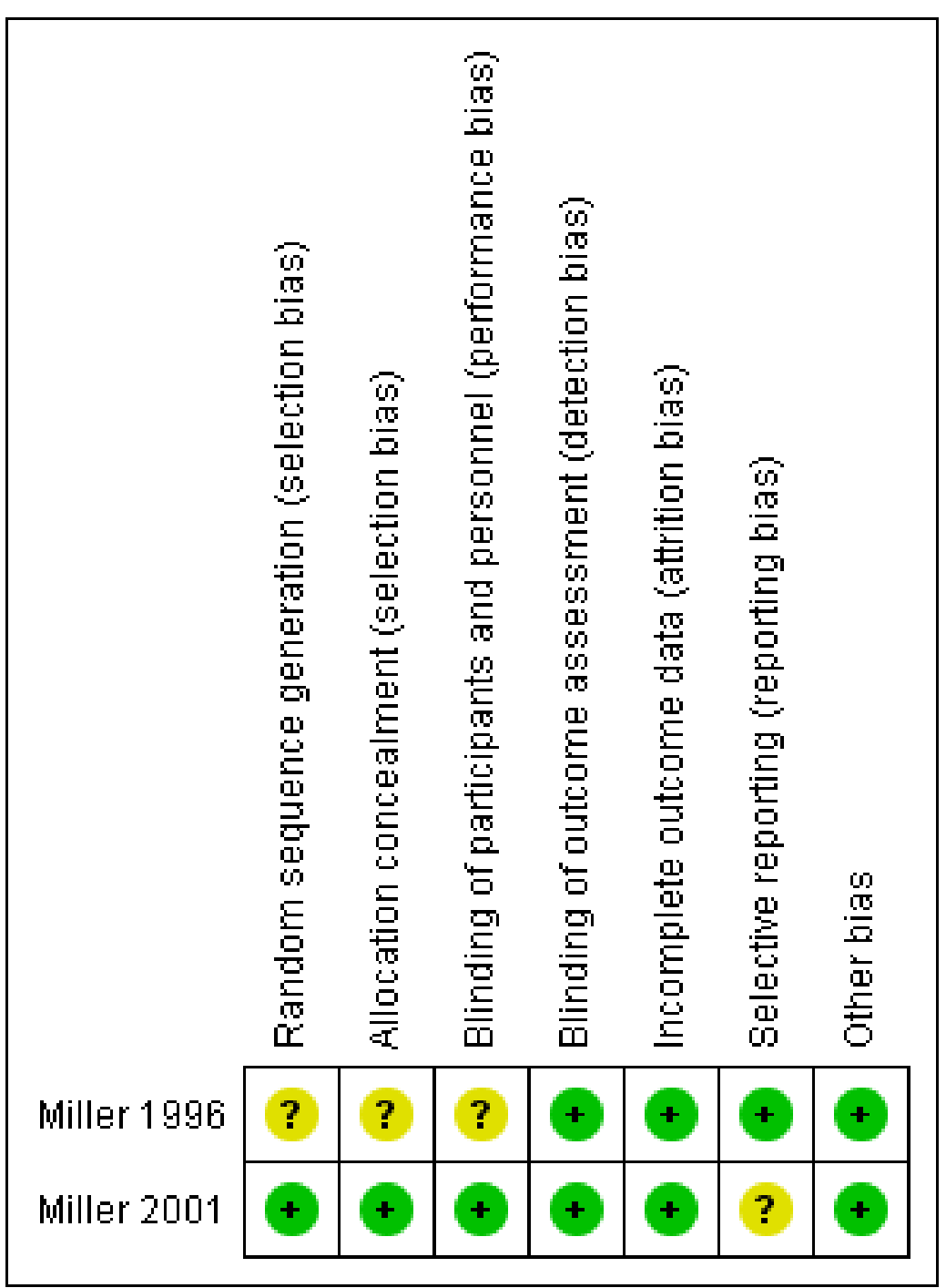

\section{Data synthesis}

We obtained Individual participant data for statistical analyses. We combined data from the two trials for meta-analysis where both trials reported the same outcome.

\section{Statistical methods}

We obtained data from the principal investigators for each participant in each of the clinical trials included in this review. For survival, we combined the data from the studies into a single data file and used the Kaplan-Meier method to estimate survival at 12 months after enrollment into the trial. We also used the log-rank statistic to test whether participants treated with gabapentin had longer survival than those treated with placebo.

Both studies used rate of decline in arm megascore strength (MVIC) of eight arm muscle groups (bilateral shoulder and elbow flexion and extension) as their primary measure of efficacy. Both studies measured MVIC every four weeks. Raw scores for MVIC were standardized to published norms using z-score transformations (raw score minus norm average divided by norm standard deviation). The arm megascore was calculated as the average zscore over all tested muscles for each participant at each visit. The primary outcome measure was the mean slope of the arm megascores (rate of decrease over time, measured in days from initial visit), for each participant in the intent-to-treat population, which included all participants randomized to a study medication (active or placebo) and having at least two visits to the center.

In the original analyses of each study a slope was estimated by linear regression for each participant and mean slopes for treated and placebo were compared using t-test or Mann-Whitney test. These analyses weighted each participant equally, regardless of the number of times each participant was evaluated.

In this meta-analysis, we pooled individual participant data from the trials and fit a linear mixed effects (Ime) model to the combined data. This model takes into account the number of times each participant is evaluated so that those with more evaluations receive greater weight when estimating model parameters. The Ime model also estimates pooled variances rather than separate ones when each participant is fit separately using linear regression. (The Ime 
model was not available for the phase II study in 1996.) We also use the Ime model to fit combined FVC data.

Our statistical model assumed that arm megascore (transformed to average z-score) and FVC declined linearly over time. When fitting the pooled data, the Ime model included fixed-effect terms for intercept (starting value), slope (rate of decline over time), and change in slope for gabapentin treatment. Random effects for intercept and slope allowed for person-to-person differences in slope and intercept and an additional random effect for each participant's deviation from the linear fit. The model is given mathematically by the formula:

$$
Y i j=(B 0+b 0 i)+\left(B 1+B 2^{\star} l i+b 1 i\right)^{\star} T i j+e i j,
$$

where i indicates participant and Tij indicates time (month of the jth measurement in the ith participant). Capital letters indicate fixedeffect coefficients and lower case letters are random effects. The term li is an indicator equal to 1 for the ith participant on active treatment and 0 for placebo. We also added fixed-effect terms to test whether treatment effects differed by trial, symptom duration, and initial arm megascore.

We used Stata version 11.0 for the above statistical analyses (Stata 2009).

\section{Other analyses}

We calculated a risk ratio (RR) with $95 \% \mathrm{Cl}$ for adverse event outcomes using the Cochrane statistical software Review Manager 5 (RevMan) (RevMan 2014).

We used a fixed-effect model for these analyses as the two included trials were performed with similar methods by the same investigators, and we consider them very likely to be measuring the same effects. We assessed heterogeneity in the meta-analyses visually and using the $\mathrm{Chi}^{2}$ test and $\mathrm{I}^{2}$ statistic calculated by RevMan. We followed guidance for rule of thumb interpretation of $\mathrm{I}^{2}$ in the Cochrane Handbook for Systematic Reviews of Interventions (Higgins 2011).

\section{'Summary of findings' table}

We created a 'Summary of findings' table showing the following outcomes.

- Survival at one year from study enrollment.

- Rate of decline of MVIC.

- Rate of decline of per cent predicted FVC.

- Rate of decline (per month) of ALSFRS.

- Health-related quality of life.

- Adverse events.

We used the five GRADE considerations (study limitations, consistency of effect, imprecision, indirectness, and publication bias) to assess the quality of a body of evidence (studies that contribute data for the prespecified outcomes). We used methods and recommendations described in Section 8.5 and Chapter 12 of the Cochrane Handbook for Systematic Reviews of Interventions (Higgins 2011). We used GRADEpro software (GRADE 2008). We used footnotes to justify any decisions to downgrade or upgrade the quality of studies and made comments to aid readers' understanding of the review where necessary.

\section{Sensitivity analysis}

We would have performed sensitivity analysis to investigate heterogeneity in the results and to assess the effect of including studies at higher risk of bias, but this was not necessary.

\section{RES U LTS}

\section{Description of studies}

\section{Results of the search}

Several searches were run in each database over a number of years. The MEDLINE and Embase filters were changed to improve specificity during review development. See Figure 2 for a PRISMA flow chart illustrating the study selection process. The combined searches found the following total number of papers in each database. 
Figure 2. Study flow diagram.

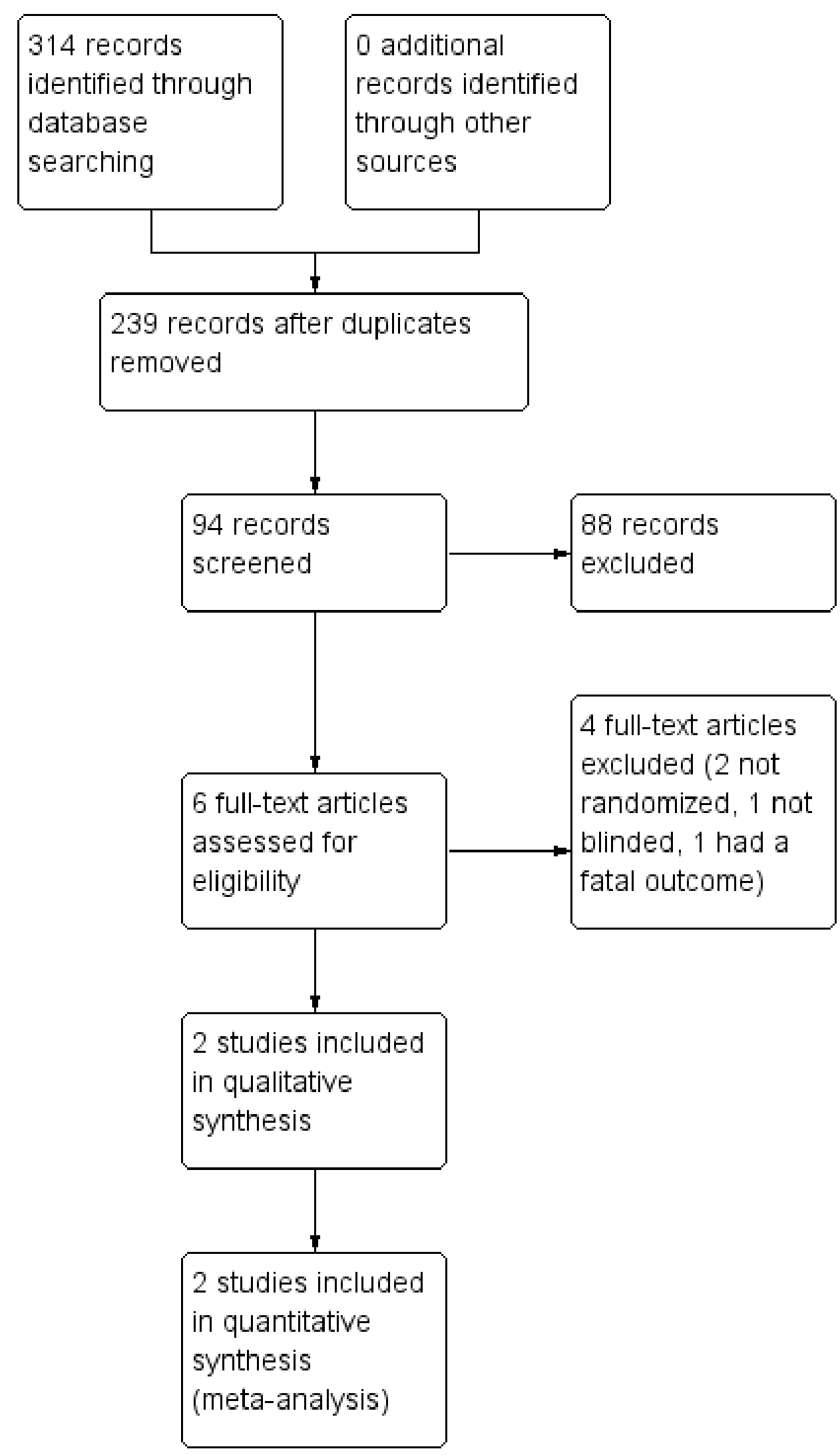


- Cochrane Neuromuscular Specialised Register - 11 papers

- CENTRAL - 10 references

- CINAHL Plus - 7 references

- AMED - 0 references

- LILACS - 0 references

We considered six studies as potentially eligible after screening titles and abstracts, but only two RCTs fulfilled selection criteria for the review (Miller 1996; Miller 2001).

\section{Included studies}

We identified two studies that fulfilled our selection criteria (Miller 1996; Miller 2001); see Characteristics of included studies. Both were randomized, placebo-controlled, double-blind studies based on the enrollment of people with a diagnosis of definite or probable ALS. In Miller 1996, the intervention consisted of oral gabapentin $800 \mathrm{mg}$ or placebo three times daily for six months. During Miller 2001, participants received oral gabapentin $1200 \mathrm{mg}$ three times daily or placebo for nine months.

\section{Excluded studies}

We excluded two studies that were not randomized (Caramia 2000; Kalra 2003). We excluded a nonblinded study on the grounds that randomized participants received different doses and schedules of gabapentin, and a nonrandomized group formed the control group (Mazzini 1998). In Norris 1979, very few baclofen-treated participants completed the trial and all had a fatal outcome. The data were too meagre for analysis. See Characteristics of excluded studies.

\section{Risk of bias in included studies}

Both studies presented a low risk of bias overall. The Miller 1996 report did not describe allocation concealment; therefore, we rated this domain and blinding of participants as unclear. Miller 2001 was at low risk of bias for all domains other than selective outcome reporting. which we rated as at unclear risk of bias, because the trialists did not fully report adverse events. See the 'Risk of bias' summary figure for an illustration of the review authors' 'Risk of bias' assessments for each trial (Figure 1) and Characteristics of included studies.

\section{Effects of interventions}

See: Summary of findings for the main comparison

\section{Gabapentin versus placebo}

Survival at one year

Not reported

\section{Arm megascores}

Overall, there was little or no difference in arm megascore decline between the gabapentin-treated group and placebo group.

The original report of results from the phase III trial noted that symptom duration was significantly shorter for participants assigned to gabapentin than for participants assigned to placebo. This report also noted a difference in arm megascore rate of decline in the placebo groups between the two trials. To account for these factors, we added terms to the Ime model to account for differences in slopes between the two trials and for symptom duration. Both of these factors were significant, that is, arm megascore slopes differed significantly in the two trials and symptom duration had a significant effect on slopes.

Table 1 summarizes the results of fitting the combined arm megascore with the Ime model $(\mathrm{N}=345)$. Interestingly, when we fit data from each trial separately, the effect of gabapentin was positive (i.e. reduced slope) in the phase II trial and was negative (i.e. increased slope) in the phase III trial. However, neither effect was statistically significant, nor was there a statistically significant difference in effect $(P=0.19$ for a differential effect; high-quality evidence).

Table 1. Results for arm megascore slopes

\begin{tabular}{lllll}
\hline & Mean slopes & \multicolumn{2}{c}{ Treatment effect } \\
\hline Descriptor & Gabapentin & Placebo & Mean & $95 \% \mathbf{C l}$ \\
\hline Separate fits & & & & \\
\hline Phase II & -0.024 & -0.032 & 0.008 & $(-0.001$ to 0.017$)$ \\
\hline Phase III & -0.026 & -0.022 & -0.004 & $(-0.010$ to 0.003$)$ \\
\hline
\end{tabular}

\section{Combined Ime fit with interaction} terms

\begin{tabular}{lllll}
\hline Phase II & -0.025 & -0.030 & 0.005 & $(-0.002$ to 0.013$)$ \\
\hline Phase III & -0.025 & -0.021 & -0.004 & $(-0.010$ to 0.003$)$ \\
\hline
\end{tabular}




\section{Forced vital capacity}

Gabapentin had little or no effect on FVC slope in either trial (see Table 2). Analysis of the combined data $(\mathrm{N}=344)$ also found no little or no effect of gabapentin on slope. The Ime model did not have to be adjusted for differences in results in the two trials and symptom duration had no effect on FVC (high-quality evidence).

Table 2. Results for FVC slopes (Ime fits)

\begin{tabular}{lllll}
\hline & \multicolumn{3}{c}{ Treatment effect } \\
\hline Descriptor & Gabapentin & Placebo & Mean & $\mathbf{9 5 \%} \mathbf{C l}$ \\
\hline Separate fits & & & \\
\hline Phase II & -0.656 & -0.593 & -0.09 & $(-0.278$ to 0.151$)$ \\
\hline Phase III & -0.635 & -0.607 & -0.028 & $(-0.234$ to 0.177$)$ \\
\hline & & & & $(-0.209$ to 0.094$)$ \\
\hline Combined fit & -0.650 & -0.593 & -0.057 & \\
\hline
\end{tabular}

\section{ALS Functional Rating Scale}

Reported in Miller 2001 but not Miller 1996. The trial demonstrated no clinically important difference in monthly rate of decline in ALSFRS in the gabapentin group versus the placebo group (moderate-quality evidence). See Table 3.

Table 3. Monthly rates of decline for ALSFRS in phase III study

\begin{tabular}{|c|c|c|c|c|}
\hline & Mean slopes & & Treatm & \\
\hline Descriptor & Gabapentin & Placebo & Mean & $95 \% \mathrm{Cl}$ \\
\hline Phase II & -0.091 & -0.076 & 0.015 & -0.34 to 0.05 \\
\hline
\end{tabular}

\section{Health-related quality of life}

Miller 2001 reported little or no difference between treatment and placebo groups in the SF-12 (Physical), with a mean change $( \pm$ standard deviation) of $-0.03( \pm 0.7)$ in the gabapentin group and $-0.2( \pm 0.5)$ in the placebo group $(P=0.19)$ (completer population, $\mathrm{N}=128$; moderate-quality evidence). Miller 1996 did not measure health-related quality of life.

\section{Survival (pooled estimate)}

There was little or no difference in estimated one-year survival between the gabapentin-treated group and the placebo group. Survival appeared to be better in the phase III study (Miller 2001) compared to the phase II study (Miller 1996), but the log-rank test comparing survival by trial in all participants suggested that it could be due to chance $(P=0.11)$. Nevertheless, to avoid bias due to possible improvement in ALS survival over calendar time, we used a stratified log-rank statistic to test for a treatment effect in the combined data. This also showed little or no difference between the two groups (high-quality evidence). (We summarize results in Table 4). 


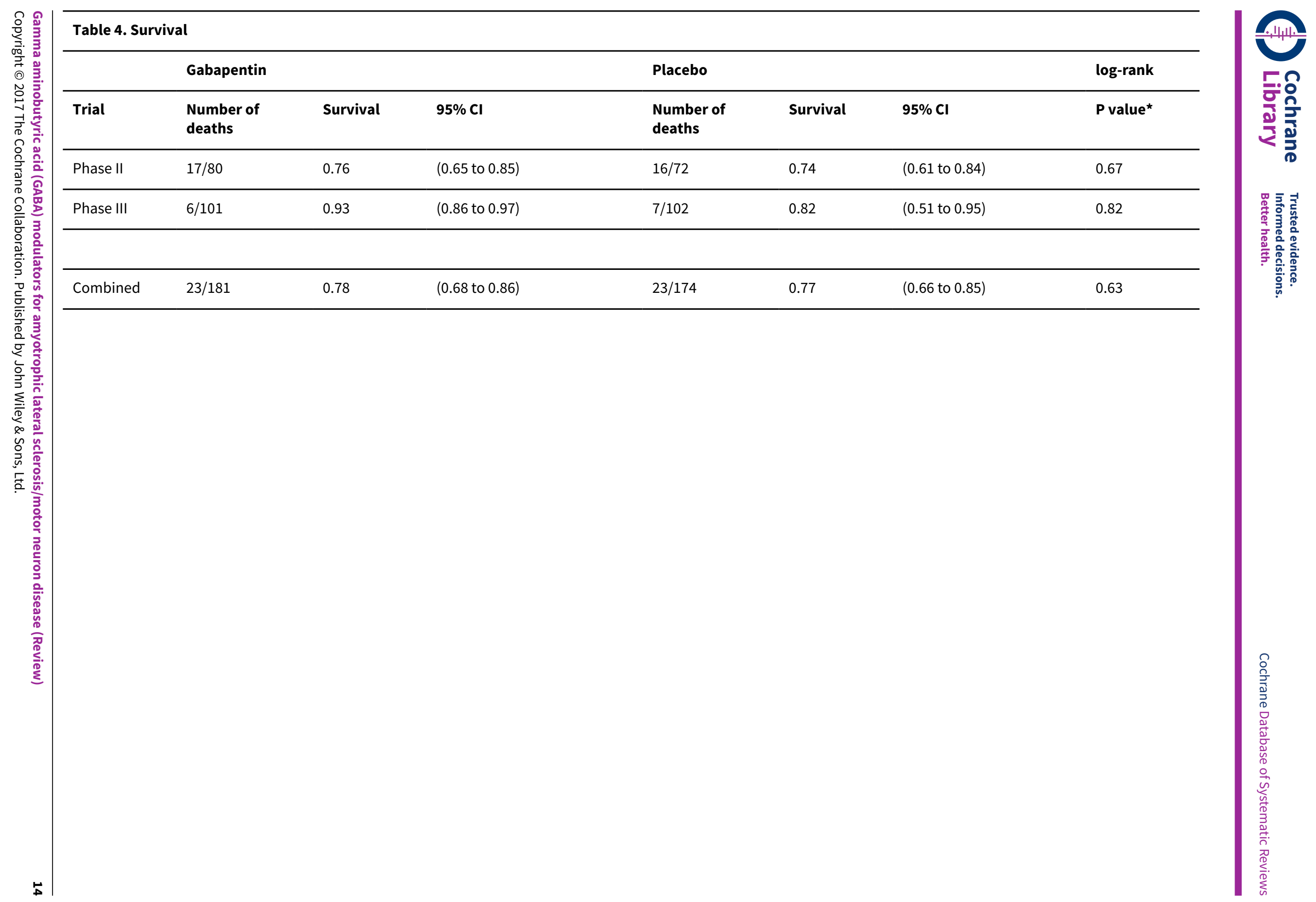


${ }^{*}$ log-rank test stratified by trial in combined data

\section{Adverse events}

The two trials reported adverse events, which were similar in kind. When we combined data from both trials ( $N=353$; highquality evidence), complaints that were elevated in those taking gabapentin were light-headedness (RR $2.80,95 \% \mathrm{Cl} 1.79$ to 4.40 ), drowsiness (RR 2.64, 95\% Cl 1.61 to 4.33), and limb swelling (RR $2.70,95 \% \mathrm{Cl} 1.45$ to 5.02 ). Falls occurred more frequently with gabapentin than placebo in Miller 2001, but not in Miller 1996 (RR from the combined analysis $1.65,95 \% \mathrm{Cl} 1.06$ to 2.57). Miller 2001 reported only these adverse events, which were those that occurred with a significantly greater frequency in the gabapentin group. We have also presented the other adverse events reported in Miller 1996 with a greater than five per cent frequency in gabapentin or placebo groups (Analysis 1.1). Miller $1996(\mathrm{~N}=149)$ reported a greater frequency of fatigue with gabapentin than with placebo (RR $3.84,95 \% \mathrm{Cl} 1.14$ to 12.92 ) and a lower frequency of headache with gabapentin than with placebo (RR $0.51,95 \% \mathrm{Cl} 0.26$ to 1.00 ), with little or no difference between the two groups in other recorded events. No important heterogeneity was apparent in the adverse event meta-analyses.

\section{DISCUSSION}

\section{Summary of main results}

We identified two RCTs of gabapentin in ALS involving a total of 355 participants and performed a meta-analysis of the combined data. The trials were to short to provide data on survival a year after enrollment, which was the primary outcome of the review. However, there was little or no difference in estimated survival at one year in the gabapentin-treated group versus the placebo group in either trial, or in the combined data. The arm megascore was the primary outcome measure of both trials. Results from the phase II trial showed a trend toward a slowing of the decline of arm megascore, even though this difference did not reach a statistical significance (defined as $P<0.05)$ (Miller 1996). Results from the randomized phase III trial (Miller 2001), as well as analysis of the combined arm megascore data from both trials, showed no therapeutic benefit with gabapentin in people with ALS. FVC, the other major outcome measure in these studies, is still an important outcome measure in ALS trials because of the importance of pulmonary function to people with ALS. Here again, there was little or no benefit from treatment. One trial measured monthly decline in the ALSFRS and quality of life using the SF-12 and found that there was probably little or no difference between groups for ALSFRS and quality of life. Drowsiness, light-headedness, and limb swelling occurred more frequently with gabapentin than with placebo, based on combined analyses. Fatigue and falls occurred more frequently with gabapentin than with placebo in one trial, but when we combined the data for fatigue from both trials, there was no clear difference between the groups.

\section{Overall completeness and applicability of evidence}

In the absence of trials of baclofen and other GABA modulators, the identified trials of gabapentin fit the overall requirements for inclusion in the review. One of the trials did not measure quality of life or ALSFRS (Miller 1996).

\section{Quality of the evidence}

We consider the two studies that were included to yield highquality evidence that gabapentin is not effective in ALS. We did not consider these studies to be completely free of any risk of bias, but both had adequate blinding, sequence generation and outcome reporting. We therefore assessed the risk of bias in these trials as low. We identified no reasons for downgrading the quality of the evidence based on the GRADE criteria of indirectness, inconsistency, publication bias, or study limitations. We downgraded quality of life and decline in ALSFRS outcomes for imprecision due to the small sample size (128 participants) of the one trial that provided data.

\section{Potential biases in the review process}

Review authors who were not investigators in the trials assessed risk of bias in the selected studies. DM was the statistician in both included studies and performed data extraction and entry for this review. He provided outcome data for checking by other review authors and the Cochrane Neuromuscular Managing Editor.

\section{Agreements and disagreements with other studies or reviews}

A Cochrane review reported that gabapentin had no benefit in trial participants with type II and III spinal muscular atrophy (SMA), which is another, more slowly progressive, motor neuron disease (Wadman 2012).

\section{AUTHORS' CONCLUSIONS}

\section{Implications for practice}

According to high-quality evidence, gabapentin is not effective in treating amyotrophic lateral sclerosis (ALS), because it neither halts nor slows progression of ALS. Gabapentin does not improve estimated survival at one year nor slow the rate of decline of muscle strength or respiratory function. Gabapentin probably has little or no effect on quality of life or monthly decline in ALS functional rating scale. No evidence from randomized trials was available for other gamma aminobutyric acid (GABA)-modulating treatments.

\section{Implications for research}

Further studies of gabapentin to slow progression of ALS are unlikely to be fruitful. The literature provides no indication of alternative promising GABA modulators.

\section{ACK N OWLEDGEMENTS}

The authors thank Ms Kate Jewitt (former Cochrane Neuromuscular Managing Editor), Ms Angela Gunn (Information Specialist) and Dr Ruth Brassington (Managing Editor) for their kind and prompt support in many circumstances. Ruth Brassington drafted 'Summary of findings' for author revision and approval, extracted and entered additional adverse event data, and carried out an additional check of outcome data entry. 


\section{RE F E R E N C E S}

\section{References to studies included in this review}

Miller 1996 \{published data only\}

* Miller RG, Moore D, Young LA, Armon C, Barohn RJ, Bromberg MB, et al. Placebo-controlled trial of gabapentin in patients with amyotrophic lateral sclerosis. WALS Study Group. Western Amyotrophic Lateral Sclerosis Study Group. Neurology 1996;47(6):1383-8. [PUBMED: 8960715]

Miller 2001 \{published data only\}

Miller RG, Moore DH 2nd, Gelinas DF, Dronsky V, Mendoza M, Barohn RJ, et al. Phase III randomized trial of gabapentin in patients with amyotrophic lateral sclerosis. Neurology 2001;56(7):843-8. [PUBMED: 11294919]

\section{References to studies excluded from this review}

Caramia 2000 \{published data only\}

Caramia MD, Palmieri MG, Desiato MT, Iani C, Scalise A, Telera S, et al. Pharmacologic reversal of cortical hyperexcitability in patients with ALS. Neurology 2000;54(1):58-64. [PUBMED: 10636126]

\section{Kalra 2003 \{published data only\}}

Kalra S, Cashman NR, Caramanos Z, Genge A, Arnold DL. Gabapentin therapy for amyotrophic lateral sclerosis: lack of improvement in neuronal integrity shown by MR spectroscopy. American Journal of Neuroradiology 2003;24(3):476-80. [PUBMED: 12637300]

\section{Mazzini 1998 \{published data only\}}

Mazzini L, Mora G, Balzarini C, Brigatti M, Pirali I, Comazzi F, et al. The natural history and the effects of gabapentin in amyotrophic lateral sclerosis. Journal of the Neurological Sciences 1998;160(Suppl 1):S57-63. [PUBMED: 9851651]

\section{Norris 1979 \{published data only\}}

Norris FH Jr, Kwei Sang U, Sachais B, Carey M. Trial of baclofen in amyotrophic lateral sclerosis. Archives of Neurology 1979;36(11):715-6. [PUBMED: 508132]

\section{Additional references}

\section{Ashworth 2012}

Ashworth NL, Satkunam LE, Deforge D. Treatment for spasticity in amyotrophic lateral sclerosis/motor neuron disease. Cochrane Database of Systematic Reviews 2012, Issue 2. [DOI: 10.1002/14651858.CD004156.pub4]

\section{Baldinger 2012}

Baldinger R, Katzberg HD, Weber M. Treatment for cramps in amyotrophic lateral sclerosis/motor neuron disease. Cochrane Database of Systematic Reviews 2012, Issue 4. [DOI: 10.1002/14651858.CD004157.pub2]

\section{Brooks 2000}

Brooks BR, Miller RG, Swash M, Munsat TL, World Federation of Neurology Research Group on Motor Neuron Diseases.
El Escorial revisited: revised criteria for the diagnosis of amyotrophic lateral sclerosis. Amyotrophic Lateral Sclerosis and Other Motor Neuron Disorders 2000;1(5):293-9.

\section{Bryans 1999}

Bryans JS, Horwell DC, Ratcliffe GS, Receveur JM, Rubin JR. An in vitro investigation into conformational aspects of gabapentin. Bioorganic and Medicinal Chemistry 1999; $7(5): 715-21$

\section{Cedarbaum 1999}

Cedarbaum JM, Stambler N, Malta E, Fuller C, Hilt D, Thurmond B, Nakanishi A. The ALSFRS-R: a revised ALS functional rating scale that incorporates assessments of respiratory function. BDNF ALS Study Group (Phase III). Journal of Neurological Sciences 1999;169(1-2):13-21.

\section{Chiò 2013}

Chiò A, Logroscino G, Traynor BJ, Collins J, Simeone JC, Goldstein LA, et al. Global epidemiology of amyotrophic lateral sclerosis: a systematic review of the published literature. Neuroepidemiology 2013;41(2):118-130.

\section{Diana 2006}

Diana A, Sogos V, Bongioanni P, Miller RG, Moore DH Gamma aminobutyric acid (GABA) modulators for amyotrophic lateral sclerosis/motor neuron disease. Cochrane Database of Systematic Reviews 2006, Issue 2. [DOI: 10.1002/14651858.CD006049]

\section{GRADE 2008 [Computer program]}

Jan Brozek, Andrew Oxman, Holger Schünemann. GRADEpro. Version 3.2 for Windows. Jan Brozek, Andrew Oxman, Holger Schünemann, 2008.

\section{Higgins 2011}

Higgins JPT, Altman DG, Sterne JAC. Chapter 8: Assessing risk of bias in included studies. In: Higgins JPT, Green S (editors). Cochrane Handbook for Systematic Reviews of Interventions Version 5.1.0 (updated March 2011). The Cochrane Collaboration, 2011. Available from www.cochranehandbook.org.

\section{Kostera 2002}

Kostera-Pruszczyk A, Niebroj-Dobosz I, Emeryk-Szajewska B, Karwańska A, Rowińska-Marcińska K. Motor unit hyperexcitability in amyotrophic lateral sclerosis vs amino acids acting as neurotransmitters. Acta Neurologica Scandinavica 2002;106(1):34-8.

\section{Lloyd 2000}

Lloyd CM, Richardson MP, Brooks DJ, Al-Chalabi A, Leigh PN. Extramotor involvement in ALS: PET studies with GABA(A) ligand [(11)C]flumazenil. Brain 2000;123(11):2289-96.

\section{Niebroj-Dobosz 1999}

Niebroj-Dobosz I, Janik P. Amino acids acting as transmitters in amyotrophic lateral sclerosis (ALS). Acta Neurologica Scandinavica 1999;100(1):6-11. 


\section{Parker 2004}

Parker DA, Ong J, Marino V, Kerr DI. Gabapentin activates presynaptic $\mathrm{GABA}_{\mathrm{B}}$ heteroreceptors in rat cortical slices. European Journal of Pharmacology 2004;495(2-3):137-43.

\section{Parmar 1998}

Parmar MK, Torri V, Stewart L. Extracting summary statistics to perform meta-analyses of the published literature for survival endpoints. Statistics in Medicine 1998;17(24):2815-34. Erratum in: Statistics in Medicine 2004; 23(11):1817.

\section{Petri 2003}

Petri S, Krampfl K, Hashemi F, Grothe C, Hori A, Dengler R, et al. Distribution of GABAA receptor mRNA in the motor cortex of ALS patients. Journal of Neuropathology and Experimental Neurology 2003;62(10):1041-51.

\section{Plaitakis 1987}

Plaitakis A, Caroscio JT. Abnormal glutamate metabolism in amyotrophic lateral sclerosis. Annals of Neurology 1987;22(5):575-9.

\section{Rand 2016}

Rand Corporation. 36-Item Short Form Survey (SF-36). www.rand.org/health/surveys_tools/mos/36-item-shortform.html (accessed prior to 26 November 2016).

\section{Rao 2004}

Rao SD, Weiss JH. Excitotoxic and oxidative cross-talk between motor neurons and glia in ALS pathogenesis. Trends in Neurosciences 2004;27(1):17-23.

\section{RevMan 2014 [Computer program]}

The Nordic Cochrane Centre, The Cochrane Collaboration. Review Manager (RevMan). Version 5.3. Copenhagen: The Nordic Cochrane Centre, The Cochrane Collaboration, 2014.

\section{Rothstein 1991}

Rothstein JD, Kuncl R, Chaudhry V, Clawson L, Cornblath DR, Coyle JT, et al. Excitatory amino acids in amyotrophic lateral sclerosis: an update. Annals of Neurology 1991;30(2):224-5.

\section{CHARACTERISTICS OF STUDIES}

Characteristics of included studies [ordered by study ID]

\section{Satzinger 1994}

Satzinger G. Antiepileptics from gamma-aminobutyric acid. Arzneimittel-Forschung 1994;44(3):261-6.

\section{Shaw 1995}

Shaw PJ, Forrest V, Ince PG, Richardson JP, Wastell HJ. CSF and plasma amino acid levels in motor neuron disease: elevation of CSF glutamate in a subset of patients. Neurodegeneration 1995;4(2):209-16.

\section{Spreux-Varoquaux 2002}

Spreux-Varoquaux O, Bensimon G, Lacomblez L, Salachas F, Pradat PF, Le Forestier N, et al. Glutamate levels in cerebrospinal fluid in amyotrophic lateral sclerosis: a reappraisal using a new HPLC method with coulometric detection in a large cohort of patients. Journal of the Neurological Sciences 2002;193(2):73-8.

\section{Stata 2009 [Computer program]}

StataCorp. Stata Statistical Software. Version 11. College Station, TX: StataCorp LP, 2009.

\section{Taylor 1994}

Taylor CP. Emerging perspectives on the mechanism of action of gabapentin. Neurology 1994;44(6 Suppl 5):S10-6; discussion S31-2.

\section{Taylor 1998}

Taylor CP, Gee NS, Su TZ, Kocsis JD, Welty DF, Brown JP, et al. A summary of mechanistic hypotheses of gabapentin pharmacology. Epilepsy Research 1998;29(3):233-49.

\section{Wadman 2012}

Wadman RI, Bosboom WMJ, van der Pol WL, van den Berg LH, Wokke JHJ, lannaccone ST, et al. Drug treatment for spinal muscular atrophy types II and III. Cochrane Database of Systematic Reviews 2012, Issue 4. [DOI: 10.1002/14651858.CD006282.pub4]

* Indicates the major publication for the study

\section{Miller 1996}

\begin{tabular}{ll}
\hline Methods & Randomized, placebo-controlled, double-blind study \\
\hline Participants & Country: USA \\
Multicenter: 8 sites \\
Diagnosis: definite or probable ALS \\
Number of participants: 152 (3 not included in the ITT analysis), 79 treated (52 male, 27 female), 70 \\
placebo ( 50 male, 20 female) \\
Age: mean 60.3 years (treated), 56.4 years (placebo)
\end{tabular}


Miller 1996 (Continued)

Inclusion criteria: people between 21 and 85 years of age who had a clinical and laboratory supported diagnosis of ALS with symptoms for no more than 3 years prior to the study

Exclusion criteria: a FVC of less than $60 \%$ of the predicted value or exclusively bulbar symptoms. For safety, the trialists also excluded people with severe bulbar involvement

\begin{tabular}{|c|c|}
\hline Interventions & Oral gabapentin $800 \mathrm{mg}$ or placebo 3 times daily for 6 months \\
\hline Outcomes & $\begin{array}{l}\text { Primary: MVIC strength of } 8 \text { arm muscle groups (bilateral shoulder and elbow flexion and extension). } \\
\text { Both MVIC and FVC were measured every } 4 \text { weeks. }\end{array}$ \\
\hline & $\begin{array}{l}\text { Secondary: rates of decline of FVC (per cent predicted) and arm megascore slope for the completer } \\
\text { population (those who had completed all } 6 \text { monthly visits) }\end{array}$ \\
\hline
\end{tabular}

Funding $\quad \begin{aligned} & \text { "Supported by Parke-Davis. The investigators received no financial incentives such as equity interest, } \\ & \text { patent rights, or corporate affiliation. Compensation was provided only for some of the costs of the } \\ & \text { study and not for reimbursement of investigator time in carrying out the trial." }\end{aligned}$

Conflicts of interest Not stated. Report lists 4 authors in Western Amyotrophic Lateral Sclerosis Study Group under the affiliation "Parke-Davis"

Notes

\section{Risk of bias}

\begin{tabular}{|c|c|c|}
\hline Bias & Authors' judgement & Support for judgement \\
\hline $\begin{array}{l}\text { Random sequence genera- } \\
\text { tion (selection bias) }\end{array}$ & Unclear risk & "Patients randomly assigned" \\
\hline $\begin{array}{l}\text { Allocation concealment } \\
\text { (selection bias) }\end{array}$ & Unclear risk & Comment: not addressed \\
\hline $\begin{array}{l}\text { Blinding of participants } \\
\text { and personnel (perfor- } \\
\text { mance bias) } \\
\text { All outcomes }\end{array}$ & Unclear risk & $\begin{array}{l}\text { Light-headedness affecting more participants in the gabapentin group may } \\
\text { have resulted in some unblinding }\end{array}$ \\
\hline $\begin{array}{l}\text { Blinding of outcome as- } \\
\text { sessment (detection bias) } \\
\text { All outcomes }\end{array}$ & Low risk & $\begin{array}{l}\text { "Clinical evaluators who measured the MVC [MVIC] were blinded and did not } \\
\text { discuss adverse events with patients" }\end{array}$ \\
\hline $\begin{array}{l}\text { Incomplete outcome data } \\
\text { (attrition bias) } \\
\text { All outcomes }\end{array}$ & Low risk & $\begin{array}{l}35 \text { dropouts ( } 17 \text { placebo, } 18 \text { gabapentin). Reasons were: adverse events (12), } \\
\text { including } 4 \text { deaths ( } 2 \text { placebo, } 2 \text { drug), noncompliance (6), advancing weak- } \\
\text { ness and inability to attend study center ( } 3 \text { ), left to participate in another trial } \\
\text { (9), eliminated because of inappropriate enrollment (2), lost to follow-up (3). } \\
5 \text { participants took } 2000 \mathrm{mg} \text { gabapentin/day, but could not tolerate } 2400 \mathrm{mg} / \\
\text { day } \\
152 \text { participants were recruited; ITT analysis for the primary outcome was per- } \\
\text { formed on } 149 \text { participants (excluding } 3 \text { people who only had one study visit). } \\
\text { A high risk of bias for secondary outcomes measured in the "completer popu- } \\
\text { lation", which was those completing all } 6 \text { monthly visits) }\end{array}$ \\
\hline
\end{tabular}

Selective reporting (re- Low risk Outcomes reported as specified in methods
porting bias)

Adverse event reporting comprehensive 
Miller 1996 (Continued)
Other bias
Low risk
Adequate

Miller 2001

\begin{tabular}{|c|c|}
\hline Methods & Randomized, placebo-controlled, double-blind study \\
\hline \multirow[t]{7}{*}{ Participants } & Country: USA \\
\hline & Multicenter: 8 sites \\
\hline & Diagnosis: definite or probable ALS \\
\hline & Number of participants: 204 (8 not included in the intent-to-treat analysis), 102 treated, 102 placebo \\
\hline & Age: 21 to 85 years \\
\hline & $\begin{array}{l}\text { Inclusion criteria: people who had a clinical and laboratory supported diagnosis of ALS with symptoms } \\
\text { for no more than } 3 \text { years prior to the study }\end{array}$ \\
\hline & $\begin{array}{l}\text { Exclusion criteria: FVC of less than } 60 \% \text { of predicted, exclusively bulbar symptoms and concomitant } \\
\text { use of riluzole }\end{array}$ \\
\hline Interventions & Oral gabapentin $1200 \mathrm{mg}$ or placebo 3 times daily for 9 months \\
\hline \multirow[t]{2}{*}{ Outcomes } & $\begin{array}{l}\text { Primary: rate of decline in MVIC strength of } 8 \text { arm muscle groups (bilateral shoulder and elbow flexion } \\
\text { and extension). }\end{array}$ \\
\hline & $\begin{array}{l}\text { Secondary: median rate of rate of decline of per cent predicted MVIC, FVC, arm megascore slope for } \\
\text { completers of study and participants above 50th percentile of strength at baseline, and rate of decline } \\
\text { of per cent predicted FVC. Investigators also recorded change during } 9 \text { months in ALSFRS, timed walk- } \\
\text { ing ( } 15 \text { feet), rapid foot taps, mortality, SF-12, and a symptom survey }\end{array}$ \\
\hline
\end{tabular}

Funding

"Supported by MDA, Warner Lambert Parke Davis, and the US FDA Office of Orphan Products Development (grant \# FD-R-001656-01)"

\begin{tabular}{ll}
\hline Conflicts of interest & Not stated \\
\hline Notes & 9-month randomized phase followed by a 6-month open follow-up (not reported in the review)
\end{tabular}

\section{Risk of bias}

\begin{tabular}{lll}
\hline Bias & Authors' judgement & Support for judgement \\
\hline $\begin{array}{ll}\text { Random sequence genera- } \\
\text { tion (selection bias) }\end{array}$ & Low risk & "Patients randomly assigned" \\
& & "The randomization was accomplished by the research pharmacist at the co- \\
& & ordinating site and the allocation of patients was known only to her"
\end{tabular}

\begin{tabular}{|c|c|c|}
\hline $\begin{array}{l}\text { Allocation concealment } \\
\text { (selection bias) }\end{array}$ & Low risk & $\begin{array}{l}\text { "The randomization was accomplished by the research pharmacist at the co- } \\
\text { ordinating site and the allocation of patients was known only to her" }\end{array}$ \\
\hline $\begin{array}{l}\text { Blinding of participants } \\
\text { and personnel (perfor- } \\
\text { mance bias) } \\
\text { All outcomes }\end{array}$ & Low risk & $\begin{array}{l}\text { Double-blinded, placebo-controlled. "All capsules were identical in appear- } \\
\text { ance" }\end{array}$ \\
\hline $\begin{array}{l}\text { Blinding of outcome as- } \\
\text { sessment (detection bias) }\end{array}$ & Low risk & Double-blinded, placebo-controlled \\
\hline
\end{tabular}


Miller 2001 (Continued)

All outcomes

\section{Incomplete outcome data Low risk} (attrition bias)

All outcomes
Negative correlations between the dropout rate and initial FVC per cent ( $\mathrm{P}=$ 0.03 ) and initial arm strength megascore, measured as a percentage of normal $(P=0.003)$; those with lower initial values were more likely to drop out

204 randomized, 102 to each group. Premature withdrawals: 27 in gabapentin group, 30 in placebo group. At the 9-month termination visit, 65 participants remained in the gabapentin group and 63 participants in the placebo group. Primary outcome measure was based on ITT population of 196/204 participants ( $4 \%$ loss)

Selective reporting (re- Unclear risk Low risk for efficacy outcomes, which were reported as specified in methods porting bias)

High risk of bias for adverse events. The report presented data only for adverse events occurring with a greater frequency in the gabapentin group

Other bias Low risk Adequate

ALS: amyotrophic lateral sclerosis

FVC: forced vital capacity

ITT: intention-to-treat

MVIC: maximum voluntary isometric contraction

Characteristics of excluded studies [ordered by study ID]

\begin{tabular}{ll}
\hline Study & Reason for exclusion \\
\hline Caramia 2000 & Non-randomized and uncontrolled \\
\hline Kalra 2003 & Non-randomized \\
\hline Mazzini 1998 & $\begin{array}{l}\text { Not blinded. Trialists considered a (nonrandomized) group of participants treated with sympto- } \\
\text { matic treatments as a control group. Randomized participants received different doses and sched- } \\
\text { ules of gabapentin }\end{array}$ \\
\hline Norris 1979 & $\begin{array}{l}\text { Only 20 participants were enrolled in this baclofen trial (9 receiving baclofen and } 11 \text { receiving } \\
\text { placebo). The } 5 \text { participants possibly experiencing beneficial effects had a fatal outcome. The data } \\
\text { were too meagre for analysis }\end{array}$ \\
\hline
\end{tabular}

\section{DATA AND ANALYSES}

\section{Comparison 1. Gabapentin versus placebo}

\begin{tabular}{lllll}
\hline $\begin{array}{l}\text { Outcome or sub- } \\
\text { group title }\end{array}$ & No. of studies & $\begin{array}{l}\text { No. of partici- } \\
\text { pants }\end{array}$ & Statistical method & Effect size \\
\hline 1 Adverse events & 2 & & Risk Ratio (M-H, Fixed, 95\% Cl) & Subtotals only \\
\hline 1.1 Light-headedness & 2 & 353 & Risk Ratio (M-H, Fixed, 95\% Cl) & $2.80[1.79,4.40]$ \\
\hline 1.2 Drowsiness & 2 & 353 & Risk Ratio (M-H, Fixed, 95\% Cl) & $2.64[1.61,4.33]$ \\
\hline
\end{tabular}




\begin{tabular}{lllll}
\hline $\begin{array}{l}\text { Outcome or sub- } \\
\text { group title }\end{array}$ & No. of studies & $\begin{array}{l}\text { No. of partici- } \\
\text { pants }\end{array}$ & Statistical method & Effect size \\
\hline 1.3 Falls & 2 & 353 & Risk Ratio (M-H, Fixed, 95\% Cl) & $1.65[1.06,2.57]$ \\
\hline 1.4 Limb swelling & 2 & 353 & Risk Ratio (M-H, Fixed, 95\% Cl) & $2.70[1.45,5.02]$ \\
\hline 1.5 Headache & 1 & 149 & Risk Ratio (M-H, Fixed, 95\% Cl) & $0.51[0.26,1.00]$ \\
\hline 1.6 Weakness & 1 & 149 & Risk Ratio (M-H, Fixed, 95\% Cl) & $2.07[0.84,5.09]$ \\
\hline 1.7 Fatigue & 1 & 149 & Risk Ratio (M-H, Fixed, 95\% Cl) & $3.84[1.14,12.92]$ \\
\hline 1.8 Diarrhea & 1 & 149 & Risk Ratio (M-H, Fixed, 95\% Cl) & $1.42[0.49,4.13]$ \\
\hline 1.9 Cramps & 1 & 149 & Risk Ratio (M-H, Fixed, 95\% Cl) & $3.54[0.78,16.14]$ \\
\hline $\begin{array}{l}1.10 \text { Shortness of } \\
\text { breath }\end{array}$ & 1 & 149 & Risk Ratio (M-H, Fixed, 95\% Cl) & $0.74[0.24,2.31]$ \\
\hline 1.11 Depression & 1 & 149 & Risk Ratio (M-H, Fixed, 95\% Cl) & $0.33[0.09,1.20]$ \\
\hline 1.12 Nausea & 1 & & & $1.11[0.31,3.96]$ \\
\hline
\end{tabular}

Analysis 1.1. Comparison 1 Gabapentin versus placebo, Outcome 1 Adverse events.

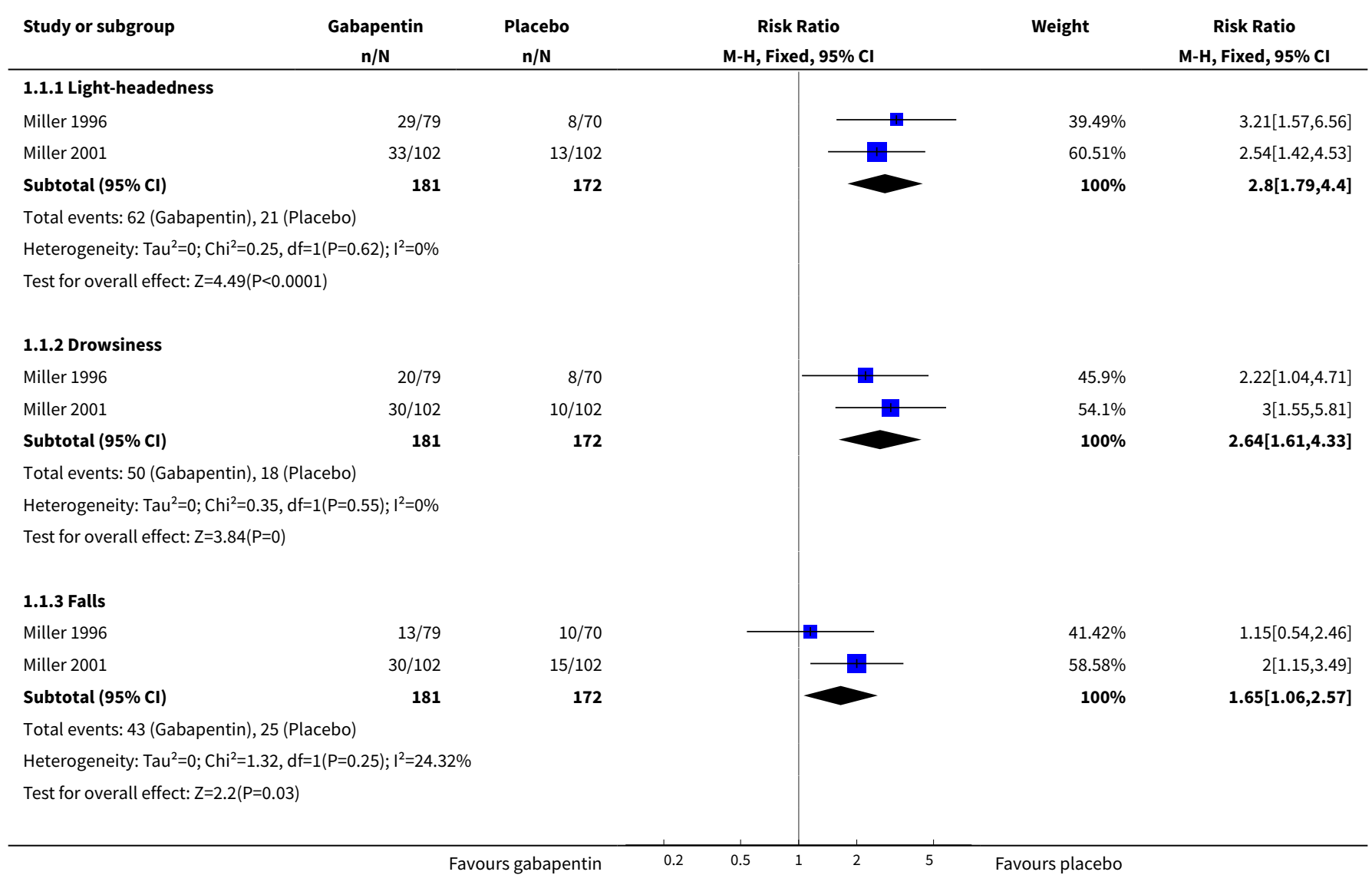




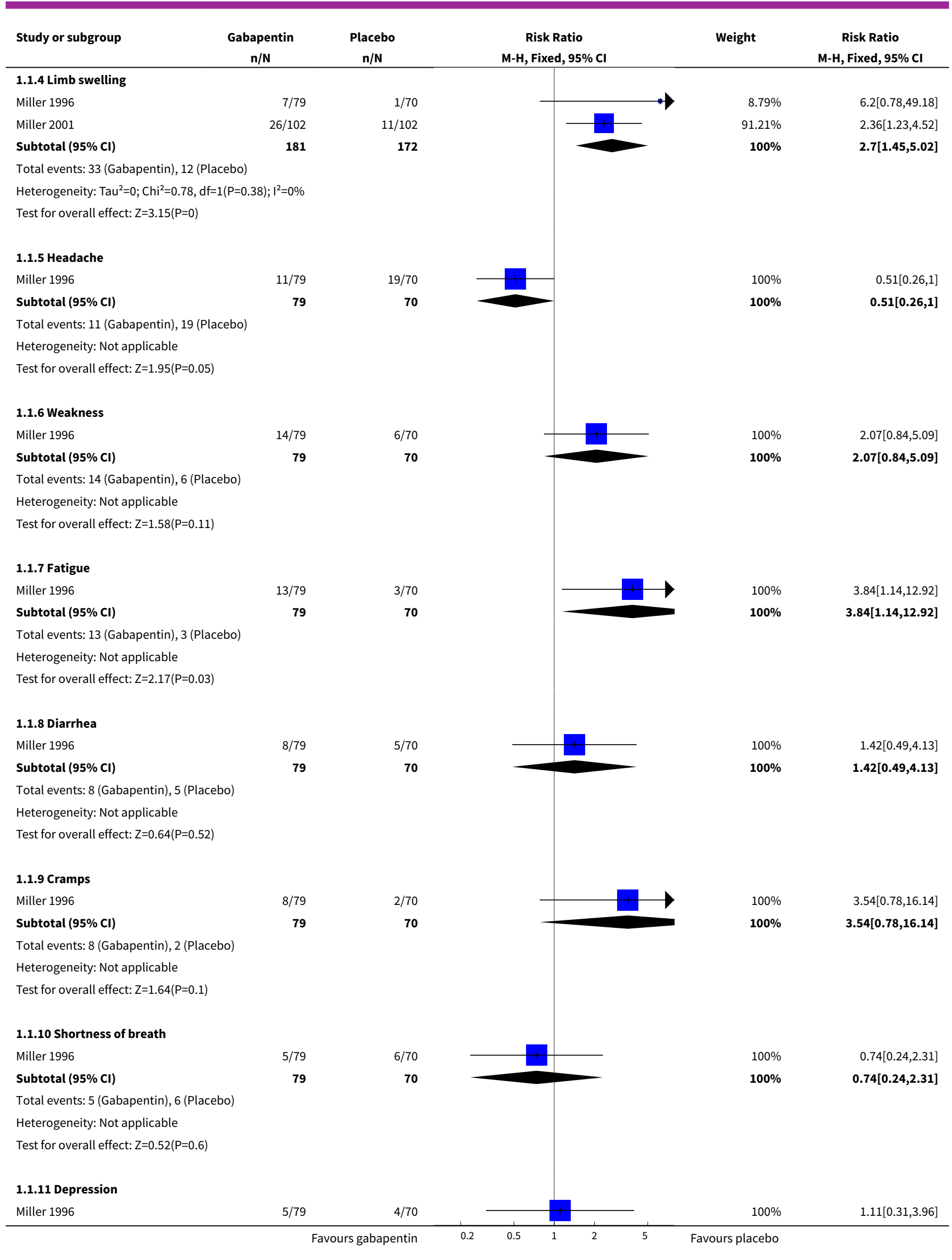




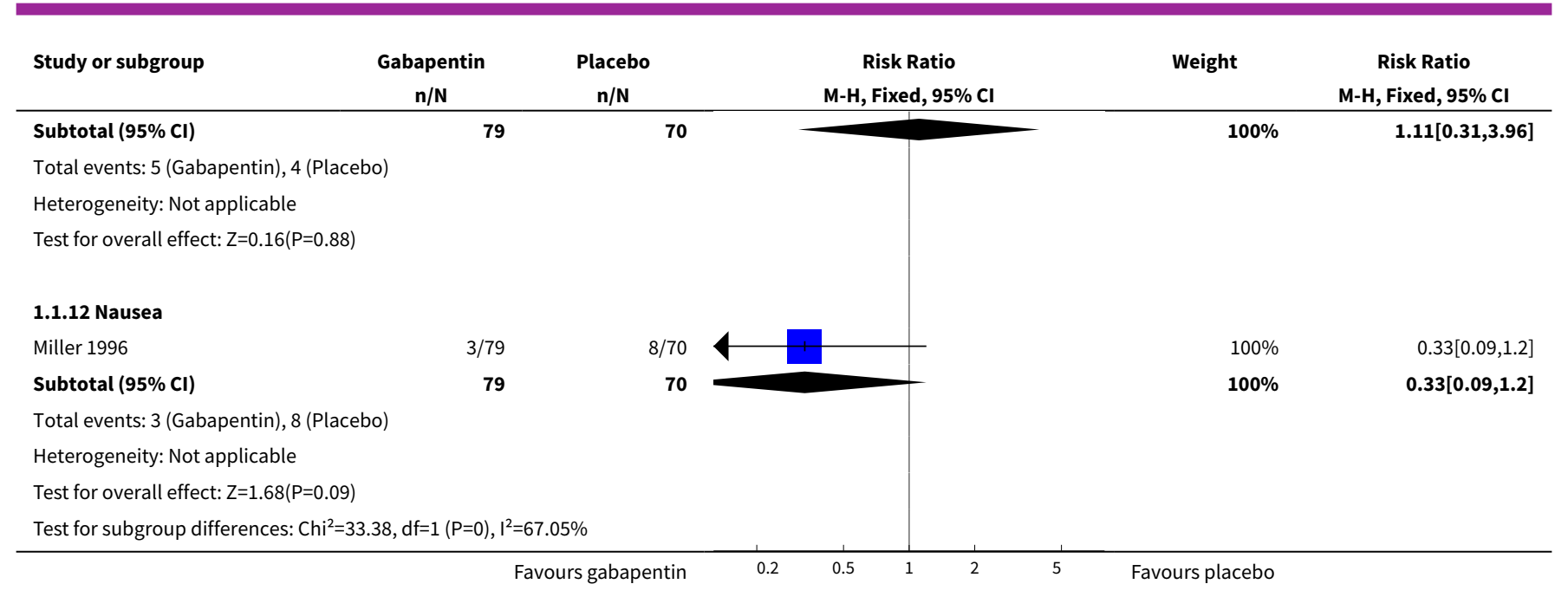

\section{APPENDICES}

\section{Appendix 1. Cochrane Neuromuscular Specialised Register (CRS) search strategy}

\#1 MeSH DESCRIPTOR Motor Neuron Disease Explode All [REFERENCE] [STANDARD]

\#2 "moto? neuron? disease?" or "moto?neuron? disease?" [REFERENCE] [STANDARD]

\#3 "charcot disease" [REFERENCE] [STANDARD]

\#4 "amyotrophic lateral sclerosis" [REFERENCE] [STANDARD]

\#5 als:ti or als:ab or nmd:ti or mnd:ab [REFERENCE] [STANDARD]

\#6 \#1 or \#2 or \#3 or \#4 or \#5 [REFERENCE] [STANDARD]

\#7 MeSH DESCRIPTOR GABA Agonists Explode All [REFERENCE] [STANDARD]

\#8 gabapentin or baclofen or gaba [REFERENCE] [STANDARD]

\#9 MeSH DESCRIPTOR gamma-Aminobutyric Acid Explode All [REFERENCE] [STANDARD]

\#10 MeSH DESCRIPTOR GABA Agonists Explode All [REFERENCE] [STANDARD]

\#11 MeSH DESCRIPTOR GABA Antagonists Explode All [REFERENCE] [STANDARD]

$\# 12 \# 7$ or \#8 or \#9 or \#10 or \#11 [REFERENCE] [STANDARD]

$\# 13 \# 6$ and \#12 [REFERENCE] [STANDARD]

$\# 14$ (\#6 and \#12) AND (INREGISTER) [REFERENCE] [STANDARD]

\section{Appendix 2. MEDLINE (OvidSP) search strategy}

Ovid MEDLINE(R) 1946 to August Week 12016

Database: Epub Ahead of Print, In-Process \& Other Non-Indexed Citations, Ovid MEDLINE(R) Daily and Ovid MEDLINE(R) $<1946$ to Present> Search Strategy:

1 randomized controlled trial.pt. (428443)

2 controlled clinical trial.pt. (91561)

3 randomized.ab. (367149)

4 placebo.ab. (177912)

5 clinical trials as topic.sh. (178961)

6 randomly.ab. (261690)

7 trial.ti. $(160523)$

8 or/1-7 (1060915)

9 exp animals/ not humans.sh. (4299403)

108 not 9 (978261)

11 exp Motor Neuron Disease/ (22613)

12 (moto\$1 neuron\$1 disease\$1 or moto?neuron\$1 disease).mp. (7547)

13 ((Lou Gehrig\$1 adj5 syndrome\$1) or (Lou Gehrig\$1 adj5 disease)).mp. (154)

14 charcot disease.tw. (20)

15 Amyotrophic Lateral Sclerosis.mp. (21046) 
16 or/11-15 (29721)

17 gabapentin.mp. (5430)

18 Baclofen/ (5141)

19 baclofen.mp. (7211)

20 exp gamma-Aminobutyric Acid/ (40627)

21 GABA.mp. (62569)

22 exp GABA Agonists/ (11455)

23 GABA Agonists.mp. (4391)

24 exp GABA Antagonists/ (26110)

25 GABA antagonists.mp. (6538)

26 or/17-25 (94735)

2710 and 16 and 26 (19)

28 remove duplicates from 27 (17)

\section{Appendix 3. Embase (OvidSP) search strategy}

Database: Embase <1980 to 2016 Week 33>

Search Strategy:

1 crossover-procedure.sh. (48263)

2 double-blind procedure.sh. (130713)

3 single-blind procedure.sh. (22711)

4 randomized controlled trial.sh. (413467)

5 (random\$ or crossover\$ or cross over\$ or placebo $\$$ or (doubl\$ adj blind\$) or allocat\$).tw,ot. (1286143)

6 trial.ti. (205330)

7 or/1-6 (1437908)

8 (animal/or nonhuman/ or animal experiment/) and human/ (1511233)

9 animal/ or nonanimal/ or animal experiment/ (3615050)

109 not 8 (2986322)

117 not 10 (1324199)

12 limit 11 to embase (1091515)

13 motor neuron disease/ or amyotrophic lateral sclerosis/ (33372)

14 (moto $\$ 1$ neuron $\$ 1$ disease $\$ 1$ or moto?neuron\$1 disease $\$ 1) . m p$. (11166)

15 ((Lou Gehrig\$1 adj5 syndrome $\$ 1$ ) or (Lou Gehrig\$1 adj5 disease)).mp. (178)

16 charcot disease.tw. (24)

17 amyotrophic lateral sclerosis.tw. (21818)

18 or/13-17 (36952)

19 Gabapentin.mp. (24567)

20 Gabapentin/ (23903)

21 gabapentin.mp. (24567)

22 Baclofen/ (15122)

23 baclofen.mp. (15808)

244 Aminobutyric Acid/ (44622)

25 gamma-aminobutyric acid.mp. (22536)

26 gamma amino butyric acid.mp. (1741)

27 GABA.mp. (56113)

28 exp 4 Aminobutyric Acid Receptor Stimulating Agent/ (66028)

29 GABA agonists.mp. (727)

30 exp 4 Aminobutyric Acid Receptor Blocking Agent/ (18889)

31 GABA antagonists.mp. (480)

32 or/19-31 (118086)

3312 and 18 and 32 (52)

34 remove duplicates from 33 (52)

\section{Appendix 4. AMED (OvidSP) search strategy}

Database: AMED (Allied and Complementary Medicine) <1985 to August 2016> Search Strategy:

1 Randomized controlled trials/ (1794)

2 Random allocation/ (313)

3 Double blind method/ (595)

4 Single-Blind Method/ (77)

Gamma aminobutyric acid (GABA) modulators for amyotrophic lateral sclerosis/motor neuron disease (Review) 
5 exp Clinical Trials/ (3561)

6 (clin\$ adj25 trial\$).tw. (6444)

7 ((singl\$ or doubl\$ or treb\$ or trip\$) adj25 (blind\$ or mask\$ or dummy)).tw. (2686)

8 placebos/ (571)

9 placebo\$.tw. (2906)

10 random $\$ . t w .(16032)$

11 research design/ (1859)

12 Prospective Studies/ (920)

13 meta analysis/ (187)

14 (meta?analys\$ or systematic review\$).tw. (2916)

15 control\$.tw. (32885)

16 (multicenter or multicentre).tw. (925)

17 ((study or studies or design\$) adj25 (factorial or prospective or intervention or crossover or cross-over or quasi-experiment\$)).tw.

(11834)

18 or/1-16 (45582)

19 exp Motor Neuron Disease/ (109)

20 (moto\$1 neuron\$1 disease\$1 or moto?neuron\$1 disease).mp. (182)

21 ((Lou Gehrig\$1 adj5 syndrome\$1) or (Lou Gehrig\$1 adj5 disease)).mp. (2)

22 charcot disease.tw. (1)

23 Amyotrophic Lateral Sclerosis/ (205)

24 amyotrophic lateral sclerosis.tw. (285)

25 or/19-24 (441)

26 gabapentin.mp. (66)

27 Baclofen/ (68)

28 baclofen.mp. (142)

29 GABA.mp. (136)

30 gamma aminobutyric acid.mp. (43)

31 or/26-29 (328)

3218 and 25 and $30(0)$

\section{Appendix 5. CINAHL (EBSCOhost) search strategy}

Tuesday, August 16, 2016 11:04:07 AM

S29 S18 and S23 and S28 7

S28 S24 or S25 or S26 or S27 4,785

S27 gabapentin or baclofen or gaba 4,785

S26 (MH "GABA") or (MH "GABA Agonists") or (MH "GABA Antagonists") 1,976

S25 (MH "Baclofen") 817

S24 (MH "Gabapentin") 731

S23 S19 or S20 or S21 or S22 6,855

S22 (Lou Gehrig* W5 syndrome*) or (Lou Gehrig* w5 disease ${ }^{\star}$ ) 36

S21 amyotrophic lateral sclerosis 3,029

S20 motor neuron disease or motor neurone disease or motoneuron* disease or motorneuron* disease 1,269

S19 (MH "Motor Neuron Diseases+") 6,261

$\mathrm{S} 18 \mathrm{~S} 1$ or S2 or S3 or S4 or S5 or S6 or S7 or S8 or S9 or S10 or S11 or S12 or S13 or S14 or S15 or S16 or S17 849,892

S17 ABAB design* 92

S16 TI random* or AB random* 177,482

S15 ( TI (cross?over or placebo* or control* or factorial or sham? or dummy)) or ( $\mathrm{AB}$ (cross? over or placebo* or control* or factorial or sham? or dummy) ) 352,654

S14 ( TI (clin* or intervention* or compar ${ }^{\star}$ or experiment* or preventive or therapeutic) or AB (clin* or intervention* or compar* or experiment ${ }^{\star}$ or preventive or therapeutic) ) and ( $\mathrm{TI}\left(\right.$ trial $\left.^{\star}\right)$ or $\mathrm{AB}\left(\right.$ trial $\left.\left.^{\star}\right)\right)$ 128,261

$\mathrm{S} 13$ ( TI (meta?analys* or systematic review*) $)$ or $\left(A B\left(\right.\right.$ meta?analys ${ }^{\star}$ or systematic review $\left.\left.{ }^{\star}\right)\right) 47,819$

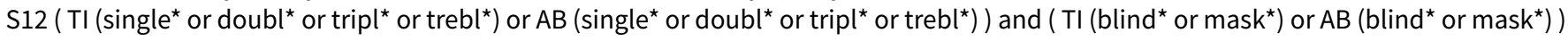

27,392

S11 PT ("clinical trial" or "systematic review") 131,810

S10 (MH "Factorial Design") 975

S9 (MH "Concurrent Prospective Studies") or (MH "Prospective Studies") 286,742

S8 (MH "Meta Analysis") 24,984

S7 (MH "Solomon Four-Group Design") or (MH "Static Group Comparison") 49

S6 (MH "Quasi-Experimental Studies") 7,952

S5 (MH "Placebos") 9,774 
S4 (MH "Double-Blind Studies") or (MH "Triple-Blind Studies") 33,819

S3 (MH "Clinical Trials+") 201,391

S2 (MH "Crossover Design") 13,883

S1 (MH "Random Assignment") or (MH "Random Sample") or (MH "Simple Random Sample") or (MH "Stratified Random Sample") or (MH "Systematic Random Sample") 73,290

\section{Appendix 6. LILACS (IAHx) search strategy}

(MH:C10.574.562\$ or "motoneuron disease" or "motor neurone disease" or "motor neuron disease" or "enfermedad de la neurona motor" or "doenca dos neuronios motores" or "amyotrophic lateral sclerosis" or "Esclerosis Amiotrófica Lateral" or "Esclerose Amiotrófica Lateral" or "Lou Gehrig Disease") and (MH:D02.241.081.160.050.350\$ or gabapentin or baclofen) and ((PT:"Randomized Controlled Trial" or "Randomized Controlled trial" or "Ensayo Clínico Controlado Aleatorio" or "Ensaio Clínico Controlado Aleatório" or PT:"Controlled Clinical Trial" or "Ensayo Clínico Controlado" or "Ensaio Clínico Controlado" or "Random allocation" or "Distribución Aleatoria" or "Distribuição Aleatória" or randon\$ or Randomized or randomly or "double blind" or "duplo-cego" or "duplo-cego" or "single blind" or "simples-cego" or "simples cego" or placebo\$ or trial or groups) AND NOT (B01.050\$ AND NOT (humans or humanos or humanos)))

\section{Appendix 7. CENTRAL (CRSO) search strategy}

Search run on Tue Aug 162016

\#1 MESH DESCRIPTOR Motor Neuron Disease EXPLODE ALL TREES 346

\#2 ("motor neuron disease" OR "motor neurone disease" OR "motoneuron disease" OR "motoneurone disease" OR "amyotrophic lateral sclerosis"):TI,AB,KY 567

\#3 \#1 or \#2 599

\#4 MESH DESCRIPTOR gamma-Aminobutyric Acid EXPLODE ALL TREES 1124

\#5 MESH DESCRIPTOR GABA Agonists EXPLODE ALL TREES 288

\#6 MESH DESCRIPTOR GABA Antagonists EXPLODE ALL TREES 413

\#7 gabapentin or baclofen or GABA 2452

\#8 \#4 OR \#5 OR \#6 OR \#73 201

\#9 \#3 AND \#8 10

\section{Appendix 8. ClinicalTrials.gov search strategy}

(motor neuron disease OR amyotrophic lateral sclerosis) AND (GABA OR baclofen OR gabapentin)

\section{Appendix 9. WHO international Clinical Trials Registry Platform search strategy}

motor neuron disease AND gaba

motor neuron disease AND gabapentin

motor neuron disease AND baclofen

amyotrophic lateral sclerosis AND gaba

amyotrophic lateral sclerosis AND gabapentin

amyotrophic lateral sclerosis AND baclofen

\section{HIS T O R Y}

Protocol first published: Issue 2, 2006

Review first published: Issue 1, 2017

\begin{tabular}{lll}
\hline Date & Event & Description \\
\hline 24 August 2008 & Amended & Converted to new review format. \\
\hline
\end{tabular}

\section{CONTRIBUTIONS OF AUTHORS}

AD drafted the protocol and carried out the literature searches and the review with PB and RM. RP replaced Valeria Sogos at the review stage. DM and RM provided the data from the two trials and DM carried out the statistical analyses. As DM was an author of the included studies, AO'K carried out an independent data extraction and checked statistical analysis using available data. 


\section{DECLARATIONS OF INTEREST}

Andrea Diana: none known.

Rita Pillai: none known.

Paolo Bongioanni: none known.

Aidan G O'Keeffe: none known.

Robert G Miller: conducted two of the clinical trials of gabapentin (Miller 1996; Miller 2001). He also served on the advisory board of the ALS CARE program, which was the recipient of an unrestricted grant from the manufacturer of the drug riluzole.

Dan H Moore: conducted two of the clinical trials of gabapentin (Miller 1996; Miller 2001). He also served on the advisory board of the ALS CARE program, which was the recipient of an unrestricted grant from the manufacturer of the drug riluzole.

\section{SOURCES OF SUPPORT}

\section{Internal sources}

- Department of Neuroscience, University of Pisa, Italy.

- Department of Neurosciences, California Pacific Medical Center, San Francisco, USA.

- Department of Epidemiology and Biostatistics, University of California, San Francisco, USA.

- Department of Biomedical Sciences, University of Cagliari, Italy.

\section{External sources}

- No sources of support supplied

\section{DIFFERENCES BETWEEN PROTOCOL AND REVIEW}

RP replaced Valeria Sogos, who was an author of the Cochrane protocol (Diana 2006). AO'K joined the authors at the review stage.

The current Cochrane 'Risk of bias' methodology (Higgins 2011) replaced the assessment of methodological quality described in the protocol. We included a 'Summary of findings' table and PRISMA flow chart, according to Cochrane requirements developed since publication of the protocol.

This review has also reported adverse effects of included interventions; we analysed adverse events using risk ratios and $95 \%$ confidence intervals. We did not plan these analyses in the original protocol.

As a change from protocol, at least two and sometimes three authors independently checked titles and abstracts retrieved by the searches.

\section{NOTES}

Further research in this area is unlikely and no update is currently planned for this review.

\section{INDEX TERMS}

\section{Medical Subject Headings (MeSH)}

Amyotrophic Lateral Sclerosis [ ${ }^{\star}$ drug therapy] [mortality]; Baclofen [therapeutic use]; Clinical Trials, Phase II as Topic; Clinical Trials, Phase III as Topic; GABA Agents [adverse effects] [^therapeutic use]; Randomized Controlled Trials as Topic; Time Factors; gammaAminobutyric Acid [adverse effects] [*therapeutic use]

\section{MeSH check words}

Adult; Humans 